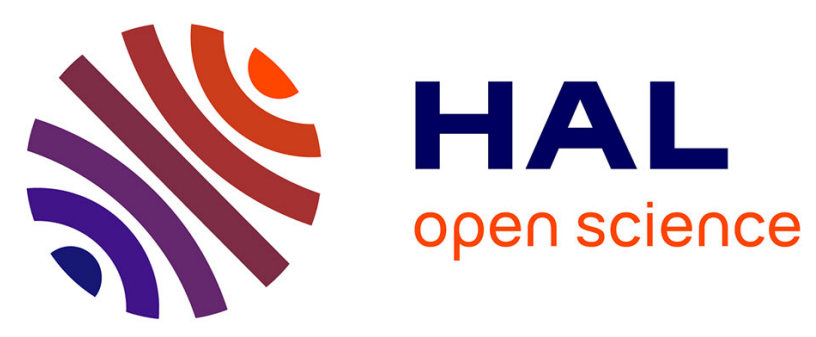

\title{
Partition locus-based classification of selected plasmids in Klebsiella pneumoniae, Escherichia coli and Salmonella enterica spp.: An additional tool
}

\author{
A. Bousquet, S. Henquet, F. Compain, N. Genel, G. Arlet, D. Decré
}

\section{- To cite this version:}

A. Bousquet, S. Henquet, F. Compain, N. Genel, G. Arlet, et al.. Partition locus-based classification of selected plasmids in Klebsiella pneumoniae, Escherichia coli and Salmonella enterica spp.: An additional tool. Journal of Microbiological Methods, 2015, 110, pp.85-91. 10.1016/j.mimet.2015.01.019 . hal-01112132

\section{HAL Id: hal-01112132 \\ https://hal.sorbonne-universite.fr/hal-01112132}

Submitted on 3 Feb 2015

HAL is a multi-disciplinary open access archive for the deposit and dissemination of scientific research documents, whether they are published or not. The documents may come from teaching and research institutions in France or abroad, or from public or private research centers.
L'archive ouverte pluridisciplinaire HAL, est destinée au dépôt et à la diffusion de documents scientifiques de niveau recherche, publiés ou non, émanant des établissements d'enseignement et de recherche français ou étrangers, des laboratoires publics ou privés. 


\section{REVISED}

Partition locus-based classification of selected plasmids in Klebsiella pneumoniae, Escherichia coli and Salmonella enterica spp: an additional tool.

Bousquet $\mathrm{A}^{* \mathrm{a}, \mathrm{b}}$, Henquet $\mathrm{S}^{\mathrm{a}, \mathrm{b}}$, Compain $\mathrm{F}^{\mathrm{a}, \mathrm{b}}$, Genel $\mathrm{N}^{\mathrm{a}, \mathrm{b}}$, Arlet $\mathrm{G}^{\mathrm{a}, \mathrm{b}, \mathrm{c}, \mathrm{d}, \mathrm{e}}$, Decré $\mathrm{D}^{\mathrm{a}, \mathrm{b}, \mathrm{e}}$

${ }^{a}$ Sorbonne University, UPMC Univ Paris 06 CR7, Paris, France.

${ }^{\mathrm{b}}$ INSERM U1135, CIMI, team E13, Paris, France.

${ }^{\mathrm{c}}$ AP-HP, Microbiology, Trousseau Hospital, Paris, France.

${ }^{\mathrm{d}}$ AP-HP, Microbiology, Tenon Hospital, Paris, France.

${ }^{\mathrm{e}}$ AP-HP, Microbiology, St-Antoine Hospital, Paris, France.

*Corresponding author: aurorebousquet@yahoo.fr // +33618030016 


\section{Introduction}

Plasmids are extrachromosomal DNA molecules capable of autonomous replication and are the main vectors of resistance and virulence genes, especially in Enterobacteriaceae. Tracing plasmids conferring drug resistance is important for analysis of evolution, epidemiology and spread of antibacterial resistance. The epidemic plasmids belong to the most frequently occurring plasmid families, however antibiotic resistance gene are not always associated with one particular replicon, transfer or partition system. Therefore is difficult to construct phylogenies of plasmids or to track the spread of particular markers.

Incompatibility (Inc) group identification has been frequently used to classify plasmids. Identification methods include the initial technique based on conjugation (Novick, 1987), hybridization with cloned replication regions (Couturier et al., 1988), PCR-based replicon typing (PBRT) (Carattoli et al., 2005) and relaxase typing (Compain et al., 2014). Moreover MLST schemes for plasmids were developed to assign plasmids to STs, in analogy to the typing developed for bacterial genomes (García-Fernández et al., 2008).

Mitotic segregation of plasmids, termed partition in bacteria, is a fundamental step of the cell cycle that ensures the transmission of the whole genome to daughter cells. It is governed by specific genetic loci named par, first identified in low-copy-number plasmids and later found to be present as homologues in most bacterial chromosomes. par loci are organized into operons encoding two proteins, an ATPase and a DNA-binding protein, and including a centromeric site. These components interact with each other to direct the subcellular localization that ensures stability of their replicons. Three types of partitioning ATPases are known (Gerdes et al., 2010): the Walker-type ATPases encoded by the par/sop gene family (type I partitioning loci which are the most common of the par systems), the actin-like ATPase encoded by the par locus of plasmid R1 (type II partitioning locus) and the tubulinlike GTPases encoded by plasmids from Bacillus sp. (type III partitioning loci). Despite their similarities in genetic organization, these three par types use entirely different molecular mechanisms (Guynet and de la Cruz, 2011).

While the acquisition of plasmids often enables bacteria to survive in the presence of antibiotics, it is possible that plasmids also confer vulnerabilities that may be exploited in tailored antibacterial therapy (Williams and Hergenrother, 2008). In order to control the spread of multiresistance plasmids, we need to determine many more variables that affect their replication, maintenance and movement. 
Recently we developed a multiplex PCR method called "plasmid relaxase gene typing" (PRaseT). This classification scheme is based on the relaxase, a key protein which is part of the mobilization region of transmissible plasmids. The aim of the present study was to identify different partition systems located on multiresistance plasmids and to design a multiplex PCR method here called "plasmid partition gene typing" (PAR-T). This method could further the classification of plasmids in Klebsiella pneumoniae, Escherichia coli and Salmonella enterica spp. and will constitute another option for characterising plasmids.

\section{Materials and methods}

\subsection{Database search, primer design and in silico primer assay}

An in silico analysis was carried out using GenBank BLAST (http://blast.ncbi.nlm.nih.gov/) on plasmids $>40 \mathrm{~kb}$ from $K$. pneumoniae and $E$. coli conferring multidrug resistance. Due to a low number of plasmids IncHI, IncI1 from K. pneumoniae, the in silico analysis was extended to some plasmids from Enterobacter cloacae and Citrobacter freundii. For the eight Inc groups studied (IncF, IncA/C, IncL/M, IncN, IncHI, IncR, IncI1, IncX), the par operon was used as template; the presence of partition-specific multidomains was searched for using CDSearch (http://www.ncbi.nlm.nih.gov/Structure/cdd/wrpsb.cgi/). Multiple alignments were performed with ClustalW2 software (http://www.ebi.ac.uk/Tools/msa/clustalw2/). Primer pairs covering most sequences in each family were designed using FastPCR (http://primerdigital.com/fastpcr.html) and Primerblast (http://www.ncbi.nlm.nih.gov/tools/primer-blast) software, while minimizing codon degeneracy (Table 1). Oligonucleotide primers were tested in silico for hybridization with plasmids from Enterobacteriaceae referenced in GenBank. 


\subsection{Bacterial strains and plasmids}

For validation of the PCR assays, experiments were conducted with 136 Escherichia coli transconjugants (Tc) or transformants (Tf) of Enterobacteriaceae (Table 2). All strains carried plasmids belonging to diverse Inc groups that encoded $\beta$-lactamases conferring resistance to third-generation cephalosporins and/or carbapenems (ESBLs, acquired cephalosporinases, carbapenemases). They were part of four collections of, respectively, (i) E. coli strains isolated between 1997 and 2002 in various French university hospitals (Marcadé et al., 2009) (Branger et al., 2005)), (ii) K. pneumoniae strains from various geographical regions collected since the 1980s (D. Decré and G.Arlet, personal collection), (iii) Salmonella enterica subsp. enterica strains representing various serovars (collection of the French National Reference Center for E. coli, Shigella sp., and Salmonella sp., Institut Pasteur), (iv) E. coli, S. enterica, K. pneumoniae strains isolated during 2013 in various Argentina University Hospitals (M. Jure, personal collection). All Tc, Tf and clinical strains used in this study were analyzed in parallel with the PAR-T and PRaseT methods. The IncR plasmids which do not encode relaxases were analyzed only by using PBRT (Carattoli et al., 2005). The Tc used as positive controls in PAR-T reactions are given in Table 2. After optimization using Tc or Tf carrying replicons of various types according to PRaseT, we applied the PAR-T method to a panel of 30 clinical strains $(17$ E. coli, $11 \mathrm{~K}$. pneumoniae and 2 S. enterica $)$ carrying replicons of one to four different types (Table 3).

\subsection{DNA extraction and PCR conditions}

Lysis by boiling was used for total DNA extraction as previously described (Dallenne et al., 2010). Multiplex PCR was carried out using the Qiagen Multiplex PCR kit (Qiagen, Courtaboeuf, France). The master mix contained pre-optimized concentrations of HotStarTaq DNA polymerase and $\mathrm{MgCl}_{2}$, deoxynucleotide triphosphate and buffer. To all multiplex PCRs, solution Q (Qiagen) that facilitates the reaction with difficult-to-amplify templates by modifying DNA melting was added. Total DNA in $2 \mu \mathrm{L}$ of bacterial lysate was subjected to multiplex PCR in a $50 \mu \mathrm{L}$ volume. The conditions for multiplex PCR were optimized to ensure that all targets were sufficiently amplified for amplicons to be easily visible on $1.5 \%$ agarose gels. The optimal primer concentrations are reported in Table 1. PCR conditions consisted of an initial activation at $95^{\circ} \mathrm{C}$ for $5 \mathrm{~min}$, followed by 35 cycles of $95^{\circ} \mathrm{C}$ for $30 \mathrm{~s}$, $57^{\circ} \mathrm{C}$ for $90 \mathrm{~s}$ and $72^{\circ} \mathrm{C}$ for $90 \mathrm{~s}$ with a final extension at $68^{\circ} \mathrm{C}$ for $10 \mathrm{~min}$; for Multiplex I and Multiplex II annealing temperature was elevated to $60^{\circ} \mathrm{C}$ for $90 \mathrm{~s}$. Simplex PCRs were 
performed in a $50 \mu \mathrm{L}$ mix with $2 \mathrm{U}$ of Taq DNA polymerase (Roche Diagnostics), $10 \times \mathrm{PCR}$ buffer $/ \mathrm{MgCl}_{2}$ (Roche Diagnostics, Meylan, France), $200 \mu \mathrm{M}$ of each deoxynucleotide triphosphate (dNTP Mix, Eurobio, Courtaboeuf, France), $0.2 \mathrm{pmol} / \mu \mathrm{L}$ of each primer, $40 \mu \mathrm{L}$ of sterile water and $2 \mu \mathrm{L}$ of total DNA extract. PCR conditions consisted in 30 cycles $\left[94^{\circ} \mathrm{C}\right.$ for $1 \mathrm{~min}, 55^{\circ} \mathrm{C}$ for $40 \mathrm{~s}, 72^{\circ} \mathrm{C}$ for $1 \mathrm{~min}$ ], preceded by 1 cycle at $94^{\circ} \mathrm{C}$ for $5 \mathrm{~min}$ and followed by 1 cycle at $72^{\circ} \mathrm{C}$ for $5 \mathrm{~min}$. PCR products were separated at $100 \mathrm{~V}$ for $90 \mathrm{~min}(180 \mathrm{~min}$ for Multiplex IV) on $1.5 \%$ agarose gel electrophoresis containing ethidium bromide and visualized using GelDoc (Biorad, Marnes-La-Coquette, France). PCR products were purified using the Exosap purification kit (Illustra Exostar-1 Step, Dutscher, Brumath, France) and subjected to bidirectional DNA sequencing using the BigDye terminator v3.1 cycle sequencing kit (Applied Biosystems, Foster City, CA, USA) and an Applied Biosystems 3730 XL capillary sequencer. Sequence analysis was carried out using Sequence scanner (Applied Biosystems), GeneDoc (www.psc.edu/biomed/genedoc) and GenBank BLAST software.

\section{Results and discussion}

\subsection{In silico analysis}

We mainly focused on plasmid families previously found to be involved in the spread of resistance genes in Enterobacteriaceae (Carattoli, 2013). The majority of plasmids contain a single par locus, with the exception of some plasmids such as pR55 plasmid which include two par loci (type I parAB and type II parMR). The type I partitioning loci are the most common of the par systems (74\%). The partition loci are often close to rep gene. In contrast, some of them are located at some distance, e.g. the parAB locus of pCTX-M-360 which is 30000 bp by away from RepA. Different designations are used in the annotated sequences for par loci: par, sop, stb. In silico analysis showed that some Inc groups are relatively homogeneous with respect their partition systems, such as IncL/M, N, A/C, I1 or R. The high sequence similarity within these groups (99-100\%) allowed designation of a pair of primers for each group. The study of the genetic environment (500 nucleotides on either side of the par genes or their equivalent) of the same groups showed high similarity (75 to 100\%). In contrast, other groups such as IncF showed more divergent par sequences. In addition, IncX plasmids from $K$. pneumoniae (e.g. pIncX-SHV, accession number JN247852 or pKPCNY79, accession number JX104759) carried a parA gene encoding a Walker-type ATPase near the rep region and an annotated parB gene $25 \mathrm{~kb}$ apart from parA without a partitionspecific multidomain. In silico analysis of IncX plasmids in E. coli showed a different 
organization from that found in $K$. pneumoniae, with parA and parB organized in an operon. In silico analysis of IncHI plasmids did not show any correlation between par loci and IncHI1 and HI2. Furthermore, the phylogram of $K$. pneumoniae in Fig. 1 reveals partition proteins form distinct subgroups and are connected to Inc group with the exceptions of plasmids IncF. In silico analysis led to the design of 18 pairs of primers targeting the par operons of plasmids from K. pneumoniae, E. coli and Salmonella enterica spp. belonging to Inc groups A/C, F, HI, I1, L/M, N, R. For plasmids belonging to the IncX group we decided to target only the parA gene (Table 1). The primer names for IncF (F1 to F9) and IncHI (HIa and HIb) groups were arbitrarily chosen.

\subsection{Primer evaluation using transconjugants and transformants}

In order to assess the sensitivity and specificity of each PCR, primers were tested using a collection of 136 recipient cells, with PRaseT as the reference method (Table 2). Each primer pair was validated using all recipient cells, first in a simplex and then a multiplex PCR and target DNA of either single cells or cell mixtures was used. PCR conditions were optimized and all amplicons were sequenced. E. coli strain J53 was used as negative control in PCR experiments to test for possible cross-hybridization with chromosomal DNA. An example of the results is shown in Fig S1. No non-specific amplification was observed. PAR-T results were largely consistent with the PRaseT results (98.6\%) except for two strains which carried an IncX replicon (E. coli strains 64 and 110). These results were surprising. If the study of IncX plasmids indicates a diversity in their backbones, no data allow an explanation as to why the par loci are organized differently in K. pneumoniae and E. coli and why there are differences in the parA genes between these two species. A complete analysis of all IncX replicon present in the databases will be required (all Enterobacteriaceae). 


\subsection{Evaluation of PAR-T using clinical strains}

Thirty clinical strains, each carrying replicons of one to four different types, were tested by PAR-T to confirm the specificity of the designed primers (Table 3). An example of the results is shown in Fig S1. For 24 strains (80\%) there was a perfect correlation between the results obtained with PAR-T and PRaseT. Six strains were positive with PRaseT but negative with PAR-T. Among these, five carried IncX replicons (four E. coli strains, i.e. 17, 19, 28 and 34, and one K. pneumoniae strain, $\mathrm{KpS} 20$ ) and one (E. coli strain 105) carried an IncI1 replicon. As shown by in silico analysis, par loci in IncX plasmids are organized differently between $K$. pneumoniae and E. coli. It is likely that our analysis targeting plasmids $>40 \mathrm{~kb}$ of $K$. pneumoniae and some E. coli did not allow the study of all the par loci of IncX plasmids. A complete analysis of all IncX replicon present in the databases will be required (all the Enterobacteriaceae). The strain (E. coli 105) that carried an IncI1 plasmid was negative with PAR-T. We considered three possibilities: (i) a divergent IncI1 par locus that could not hybridize with our primers was present, (ii) the par locus was truncated or (iii) the gene locus was absent. In silico analysis has shown that the par sequences of IncI1 replicons are well conserved and form a homogen group, thus making the first possibility (i) unlikely.

Overall the specificity were very high $(>90 \%)$ for all Inc groups studied except IncX.

Finally, four strains (E. coli 19 and 34, and K. pneumoniae KpS5 and KpS26) which were negative with PRaseT were found to contain IncF and IncR plasmids, respectively, when PAR-T was used. For the $K$. pneumoniae strains, the results were not unexpected as IncR plasmids do not encode relaxases. The two E. coli were positive with PBRT with IncFIA, IncFIB and IncFII replicons found in both. Moreover, PCR targeting the genes of the type IV secretion system was negative and the plasmids from neither strain could be transferred to a recipient cell by conjugation (Compain et al., 2014). We considered the possibility of the loss of genes for conjugative transfer. 


\section{Conclusions}

Considering the complexity of constant plasmid evolution and the unavailability of full-length plasmid sequencing in most laboratories, the combined use of several complementary classification methods should be a practical value. Our set of seven multiplex PCRs allowed classification of the most frequently encountered transmissible plasmids in Klebsiella pneumoniae, Escherichia coli and Salmonella enterica spp. by targeting their par loci, with the exception of IncX replicons. For this group, in silico analysis of all plasmids present in the databases must be carried out to design new primers and to improve the value of the method described here.

\section{$\underline{\text { Conflicting interest }}$}

The authors declare that they have no conflicting interests. 
Branger, C., Zamfir, O., Geoffroy, S., Laurans, G., Arlet, G., Thien, H.V., Gouriou, S., Picard, B., Denamur, E., 2005. Genetic background of Escherichia coli and extendedspectrum beta-lactamase type. Emerg. Infect. Dis. 11, 54-61.

Carattoli, A., 2013. Plasmids and the spread of resistance. Int. J. Med. Microbiol. IJMM 303, 298-304.

Carattoli, A., Bertini, A., Villa, L., Falbo, V., Hopkins, K.L., Threlfall, E.J., 2005a. Identification of plasmids by PCR-based replicon typing. J. Microbiol. Methods 63, 219-228.

Compain, F., Poisson, A., Le Hello, S., Branger, C., Weill, F.-X., Arlet, G., Decré, D., 2014. Targeting relaxase genes for classification of the predominant plasmids in Enterobacteriaceae. Int. J. Med. Microbiol. IJMM 304, 236-242.

Couturier, M., Bex, F., Bergquist, P.L., Maas, W.K., 1988. Identification and classification of bacterial plasmids. Microbiol. Rev. 52, 375-395.

Dallenne, C., Da Costa, A., Decré, D., Favier, C., Arlet, G., 2010. Development of a set of multiplex PCR assays for the detection of genes encoding important beta-lactamases in Enterobacteriaceae. J. Antimicrob. Chemother. 65, 490-495.

García-Fernández, A., Chiaretto, G., Bertini, A., Villa, L., Fortini, D., Ricci, A., Carattoli, A., 2008. Multilocus sequence typing of IncI1 plasmids carrying extended-spectrum betalactamases in Escherichia coli and Salmonella of human and animal origin. J. Antimicrob. Chemother. 61, 1229-1233.

Gerdes, K., Howard, M., Szardenings, F., 2010. Pushing and pulling in prokaryotic DNA segregation. Cell 141, 927-942.

Guynet, C., de la Cruz, F., 2011. Plasmid segregation without partition. Mob. Genet. Elem. 1, 236-241.

Marcadé, G., Deschamps, C., Boyd, A., Gautier, V., Picard, B., Branger, C., Denamur, E., Arlet, G., 2009. Replicon typing of plasmids in Escherichia coli producing extendedspectrum beta-lactamases. J. Antimicrob. Chemother. 63, 67-71.

Novick, R.P., 1987. Plasmid incompatibility. Microbiol. Rev. 51, 381-395.

Williams, J.J., Hergenrother, P.J., 2008. Exposing plasmids as the Achilles' heel of drugresistant bacteria. Curr. Opin. Chem. Biol. 12, 389-399. 


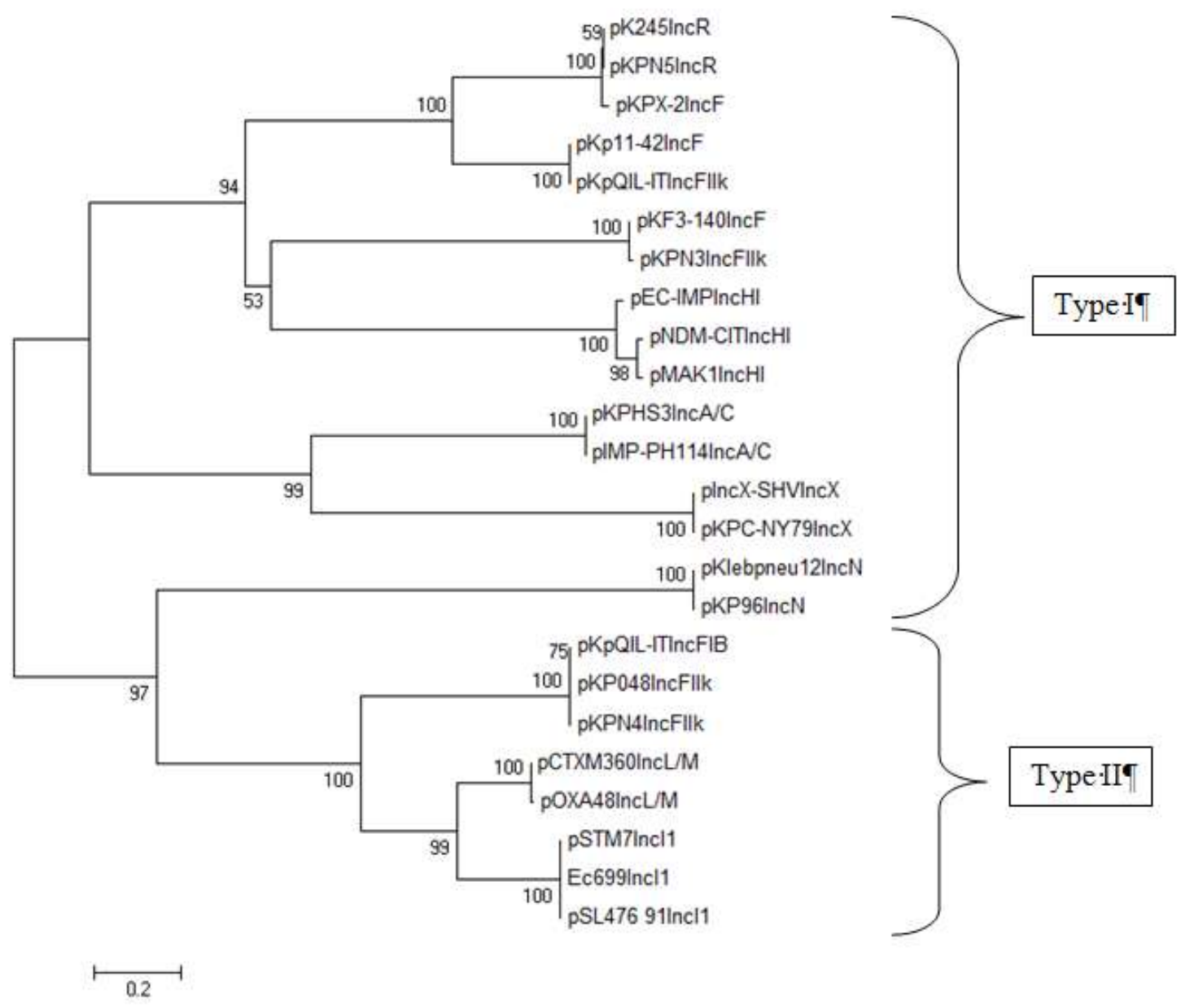

Figure 1. Phylogram of the partition proteins. Unrooted evolutionary tree showing 24 ParA and ParB proteins (or equivalent) from plasmid of K. pneumoniae, E. coli, Salmonella spp., C. freundii, E. cloacae. pKpQIL-IT include two par loci. Types I and II refer to the two types of plasmid-encoded partitioning loci shown in Fig. 1 and described in the text. The phylogram was constructed using Mega5 (Neighbor-Joining algorithm, bootstrap: 1000 replication). 
Table 1. Primers used in this study.

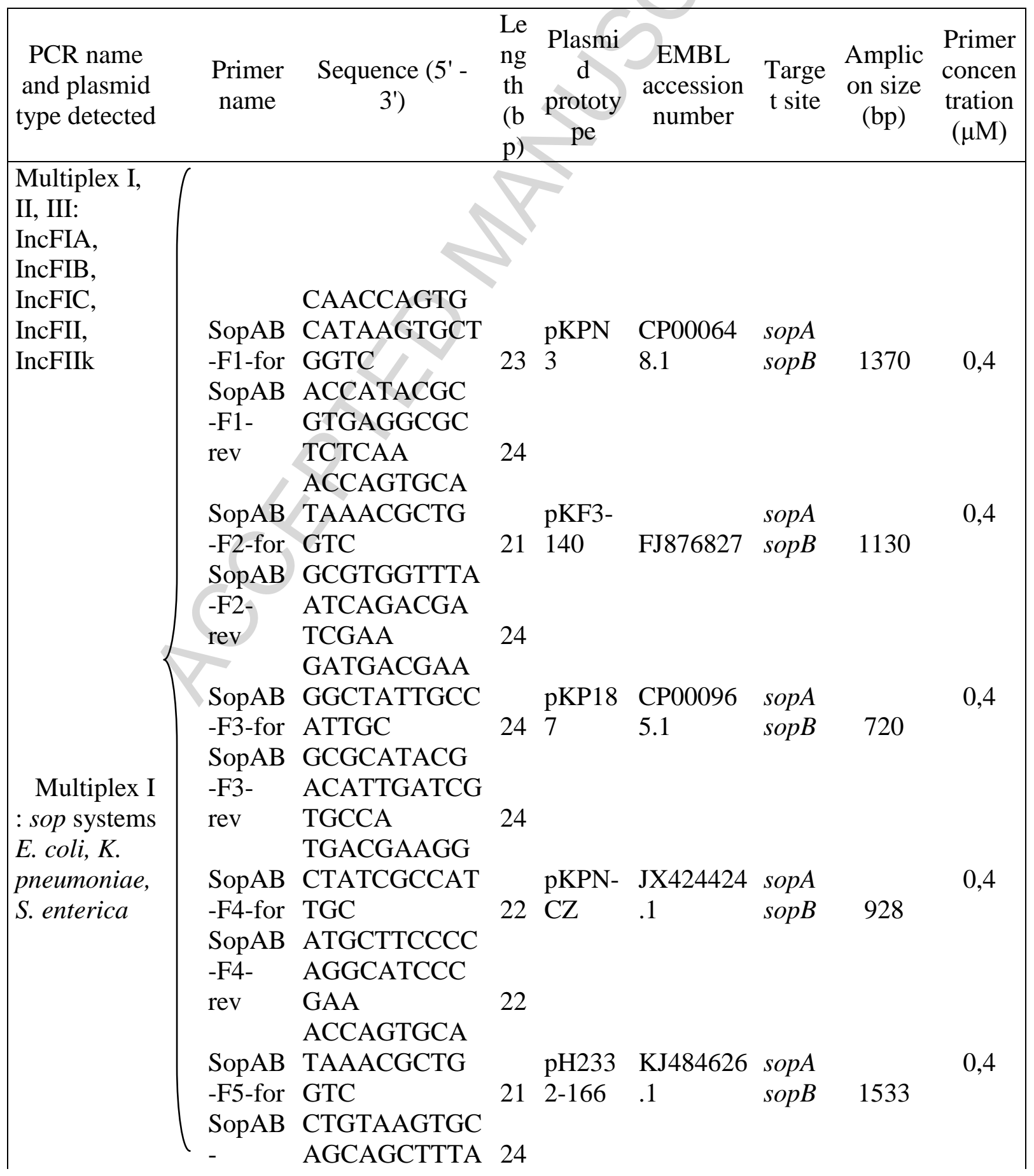




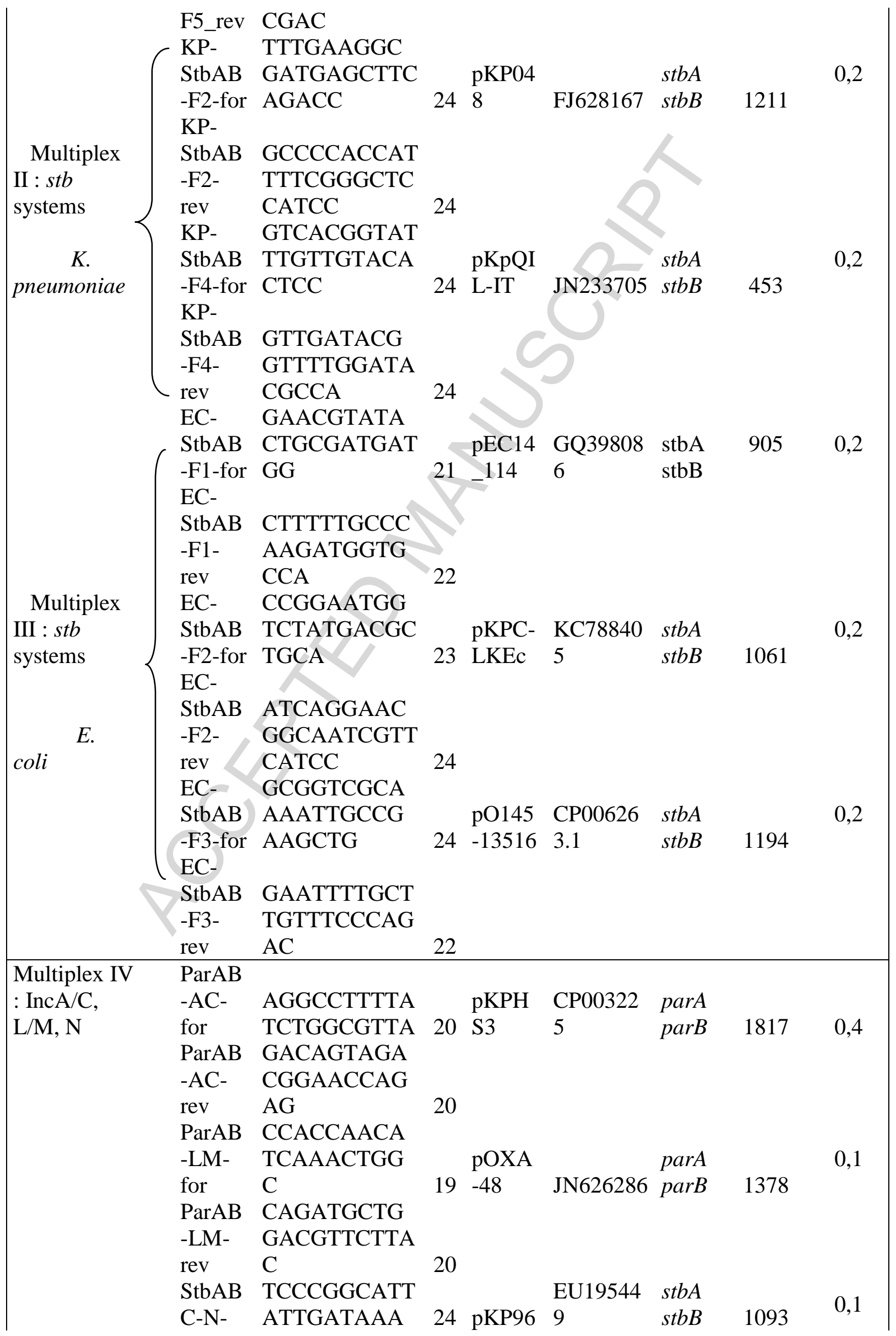




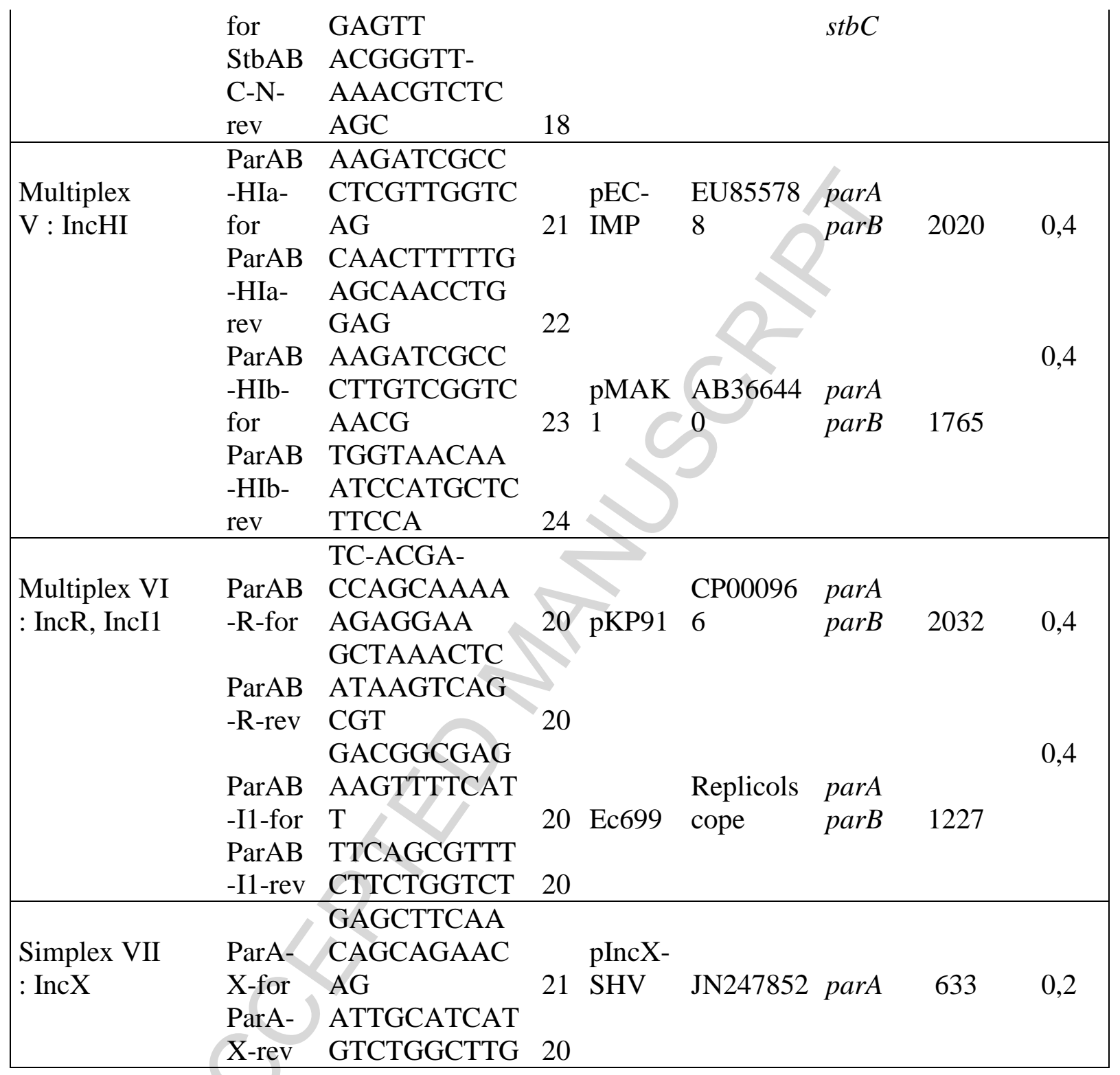


Table 2. Recipient cells used in validation experiments. Tc : transconjugants, $\mathrm{Tf}$ : transformant, PRaseT : plasmid relaxase gene typing, PBRT : PCR-based replicon typing, PAR-T : plasmid partitioning genes typing. $\dagger:$ Tc used as a positive control in partitioning genes typing.

\begin{tabular}{|c|c|c|c|c|c|}
\hline \multirow[t]{2}{*}{$\mathrm{N}^{\circ}$} & \multirow[t]{2}{*}{ Parental strain } & \multirow[t]{2}{*}{$\mathrm{Tc} / \mathrm{Tf}$} & \multirow[t]{2}{*}{$\beta$-Lactamase } & \multicolumn{2}{|c|}{ Plasmid classification } \\
\hline & & & & $\begin{array}{c}\text { PRaseT } \\
\text { (and/or PBRT) }\end{array}$ & PAR-T \\
\hline 48 & E. coli & $\mathrm{Tc}$ & TEM-52 & $\mathrm{X} 1$ & $\mathrm{X}$ \\
\hline 51 & E. coli & Tc & TEM-3 & $\mathrm{L} / \mathrm{M}$ & $X$ \\
\hline 52 & E. coli & Tf & TEM-52 & $\mathrm{X} 1$ & $\mathrm{X}$ \\
\hline 57 & E. coli & Tc & SHV-12 & $\mathrm{F}$ & $\mathrm{F}$ \\
\hline 62 & E. coli & Tc & SHV-2 & FIB & $\mathrm{F}$ \\
\hline 64 & E. coli & Tc & SHV-5 & $\mathrm{X} 4$ & - \\
\hline 73 & E. coli & Tc & SHV-4 & FIIK & FIIK \\
\hline 85 & E. coli & Tf & CTX-M-1 & FIA & $\mathrm{F}$ \\
\hline 91 & E. coli & Tc & CTX-M-3 & $\mathrm{N}$ & $\mathrm{N}$ \\
\hline $94 \dagger$ & E. coli & Tc & CTX-M-9 & FII & $\mathrm{F}$ \\
\hline 98 & E. coli & $\mathrm{Tc}$ & CTX-M-1 & $\mathrm{X} 1$ & $X$ \\
\hline 100 & E. coli & Tc & CTX-M-1 & FIA, FII & $\mathrm{F}$ \\
\hline 102 & E. coli & Tc & CTX-M-1 & HI2 & HIa \\
\hline 104 & E. coli & $\mathrm{Tf}$ & CTX-M-1 & FIA, FIB, FII & $\mathrm{F}$ \\
\hline 105 & E. coli & Tc & CTX-M-1 & $\mathrm{L} / \mathrm{M}$ & $\mathrm{L} / \mathrm{M}$ \\
\hline 108 & E. coli & $\mathrm{Tf}$ & CTX-M-1 & FIA & F \\
\hline 110 & E. coli & Tc & CTX-M-1 & $\mathrm{X} 4$ & - \\
\hline $111 \dagger$ & E. coli & Tc & CTX-M-1 & FIA & $\mathrm{F}$ \\
\hline 114 & E. coli & Tc & CTX-M-1 & $\mathrm{L} / \mathrm{M}$ & $\mathrm{L} / \mathrm{M}$ \\
\hline 115 & E. coli & Tc & СТX-M-9 & FII & $\mathrm{F}$ \\
\hline 118 & E. coli & Tc & CTX-M-1 & FIA, FIB & $\mathrm{F}$ \\
\hline 120 & E. coli & Tc & CTX-M-3 & FIB & $\mathrm{F}$ \\
\hline 122 & E. coli & Tc & СТХ-M-9 & FII & $\mathrm{F}$ \\
\hline 125 & E. coli & Tc & CTX-M-1 & FII & $\mathrm{F}$ \\
\hline 126 & E. coli & Tc & CTX-M-1 & $\mathrm{N}$ & $\mathrm{N}$ \\
\hline 127 & E. coli & Tc & CTX-M-3 & FIB & $\mathrm{F}$ \\
\hline Levy & E. coli & Tc & OXA-48 & $\mathrm{L} / \mathrm{M}$ & $\mathrm{L} / \mathrm{M}$ \\
\hline AD-48 & E. coli & Tc & OXA-48 & $\mathrm{L} / \mathrm{M}$ & $\mathrm{L} / \mathrm{M}$ \\
\hline AD-50 & E. coli & Tc & OXA-48 & $\mathrm{L} / \mathrm{M}$ & $\mathrm{L} / \mathrm{M}$ \\
\hline AD-17 & E. coli & Tc & OXA-48 & $\mathrm{L} / \mathrm{M}$ & $\mathrm{L} / \mathrm{M}$ \\
\hline AD-44-2 & E. coli & Tc & NDM-1 & $\mathrm{N}$ & $\mathrm{N}$ \\
\hline AD-2 & E. coli & Tc & OXA-48 & $\mathrm{L} / \mathrm{M}$ & $\mathrm{L} / \mathrm{M}$ \\
\hline Goe-137 & E. coli & $\mathrm{Tc}$ & VIM & HI2 & $\mathrm{HIa}$ \\
\hline Goe-132 & E. coli & Tc & VIM & $\mathrm{A} / \mathrm{C}$ & $\mathrm{A} / \mathrm{C}$ \\
\hline KATS & E. coli & $\mathrm{Tc}$ & NDM-1, CTX-M-1 & $\mathrm{F}$ & $\mathrm{F}$ \\
\hline M-2 & E. coli & Tc & KPC-2 & $\mathrm{L} / \mathrm{M}$ & $\mathrm{L} / \mathrm{M}$ \\
\hline M-3 & E. coli & Tc & KPC-2 & $\mathrm{L} / \mathrm{M}$ & $\mathrm{L} / \mathrm{M}$ \\
\hline M-5 & E. coli & Tc & KPC-2 & $\mathrm{L} / \mathrm{M}$ & $\mathrm{L} / \mathrm{M}$ \\
\hline Ec50 & E. coli & Tc & TEM-52 & I1 & I1 \\
\hline $\mathrm{S} 1$ & K. pneumoniae & Tc & CMY-4 & $\mathrm{A} / \mathrm{C}$ & $\mathrm{A} / \mathrm{C}$ \\
\hline
\end{tabular}




\begin{tabular}{|c|c|c|c|c|c|}
\hline S3 & K. pneumoniae & $\mathrm{Tc}$ & FOX-3 & $\mathrm{A} / \mathrm{C}$ & $\mathrm{A} / \mathrm{C}$ \\
\hline S4 & K. pneumoniae & $\mathrm{Tc}$ & DHA-1 & $\mathrm{A} / \mathrm{C}$ & $\mathrm{A} / \mathrm{C}$ \\
\hline S6 & K. pneumoniae & $\mathrm{Tc}$ & SHV-5 & $\mathrm{A} / \mathrm{C}$ & $\mathrm{A} / \mathrm{C}$ \\
\hline S8 & K. pneumoniae & $\mathrm{Tc}$ & CMY-2 & $\mathrm{A} / \mathrm{C}$ & $\mathrm{A} / \mathrm{C}$ \\
\hline S9 & K. pneumoniae $\dagger$ & $\mathrm{Tc}$ & SHV-4 & FIIk & $\mathrm{F}$ \\
\hline S10 & K. pneumoniae & $\mathrm{Tc}$ & ACC-1 & $\mathrm{A} / \mathrm{C}$ & $\mathrm{A} / \mathrm{C}$ \\
\hline S11 & K. pneumoniae & $\mathrm{Tc}$ & CMY-4 & $\mathrm{A} / \mathrm{C}$ & $\mathrm{A} / \mathrm{C}$ \\
\hline S12 & K. pneumoniae & $\mathrm{Tc}$ & SHV-2, DHA-1 & FIIk, R & $\mathrm{F}, \mathrm{R}$ \\
\hline S13 & K. pneumoniae & $\mathrm{Tc}$ & $\begin{array}{l}\text { SHV-1 } \\
-\mathrm{M}-15 \mathrm{CMV}\end{array}$ & $\mathrm{A} / \mathrm{C}$ & $\mathrm{A} / \mathrm{C}$ \\
\hline $\mathrm{S} 14 \dagger$ & K. pneumoniae & $\mathrm{Tc}$ & 4, VIM-4 & $\mathrm{A} / \mathrm{C}$ & $\mathrm{A} / \mathrm{C}$ \\
\hline S16 & K. pneumoniae & $\mathrm{Tc}$ & CTX-M-3 & $\mathrm{A} / \mathrm{C}$ & $\mathrm{A} / \mathrm{C}$ \\
\hline S18 & K. pneumoniae & $\mathrm{Tc}$ & 15 & $\mathrm{~F}$ & $\mathrm{~F}$ \\
\hline & & & OXA-1, CTX-M- & & \\
\hline $\mathrm{S} 19 \dagger$ & K. pneumoniae & $\mathrm{Tc}$ & 15 & $\mathrm{~N}$ & $\mathrm{~N}$ \\
\hline \multirow[t]{2}{*}{$\mathrm{S} 20$} & K. pneumoniae & $\mathrm{Tc}$ & OXA-1, SHV-2a, & & \\
\hline & & & CTX-M-15 & $\mathrm{F}$ & $\mathrm{F}$ \\
\hline $\mathrm{S} 21$ & K. pneumoniae & $\mathrm{Tc}$ & TEM-3 & $\mathrm{A} / \mathrm{C}$ & $\mathrm{A} / \mathrm{C}$ \\
\hline S23 & K. pneumoniae & $\mathrm{Tc}$ & CTX-M- 3 & $\mathrm{~N}, \mathrm{~A} / \mathrm{C}$ & $\mathrm{N}, \mathrm{A} / \mathrm{C}$ \\
\hline S24 & K. pneumoniae & Tc & TEM-3 & $\mathrm{A} / \mathrm{C}$ & $\mathrm{A} / \mathrm{C}$ \\
\hline S26 & K. pneumoniae & Tc & SHV-12 & $\mathrm{N}$ & $\mathrm{N}$ \\
\hline S28 & K. pneumoniae & $\mathrm{Tc}$ & DHA-1 & $\mathrm{L} / \mathrm{M}$ & $\mathrm{L} / \mathrm{M}$ \\
\hline $\mathrm{S} 30 \dagger$ & K. pneumoniae & $\mathrm{Tf}$ & OXA-1, DHA-1 & $\mathrm{R}$ & $\mathrm{R}$ \\
\hline S33 & K. pneumoniae & $\mathrm{Tf}$ & DHA-1 & $\mathrm{R}$ & $\mathrm{R}$ \\
\hline $\mathrm{S} 34 \dagger$ & K. pneumoniae & Tc & DHA-1 & $\mathrm{L} / \mathrm{M}$ & $\mathrm{L} / \mathrm{M}$ \\
\hline S36 & K. pneumoniae & $\mathrm{Tc}$ & OXA-1, CTX-M-3 & FII & $\mathrm{F}$ \\
\hline S43 & K. pneumoniae & $\mathrm{Tc}$ & CTX-M-3 & $\mathrm{N}$ & $\mathrm{N}$ \\
\hline S45 & K. pneumoniae & $\mathrm{Tc}$ & $\begin{array}{c}\text { OXA-1, CTX-M- } \\
15\end{array}$ & $\mathrm{~L} / \mathrm{M}$ & $\mathrm{L} / \mathrm{M}$ \\
\hline S46 & K. pneumoniae & $\mathrm{Tc}$ & CTX-M-15 & $\mathrm{L} / \mathrm{M}$ & $\mathrm{L} / \mathrm{M}$ \\
\hline S47 & K. pneumoniae & $\mathrm{Tc}$ & CTX-M-3 & $\mathrm{L} / \mathrm{M}$ & $\mathrm{L} / \mathrm{M}$ \\
\hline S48 & K. pneumoniae & $\mathrm{Tc}$ & CTX-M-15 & $\mathrm{L} / \mathrm{M}$ & $\mathrm{L} / \mathrm{M}$ \\
\hline S49 & K. pneumoniae & $\mathrm{Tc}$ & CTX-M-15 & $\mathrm{L} / \mathrm{M}$ & $\mathrm{L} / \mathrm{M}$ \\
\hline S51 & K. pneumoniae & Tc & SHV-12 & FIIk & $\mathrm{F}$ \\
\hline \multirow[t]{2}{*}{ S53 } & K. pneumoniae & $\mathrm{Tc}$ & SHV-12 & $\mathrm{R}$ & $\mathrm{R}$ \\
\hline & & & OXA-1, CTX-M- & & \\
\hline S55 & K. pneumoniae & $\mathrm{Tc}$ & 15 & FIIk & $\mathrm{F}$ \\
\hline & & & OXA-1, CTX-M- & & \\
\hline S56 & K. pneumoniae & $\mathrm{Tc}$ & 15 & FIIk R & $\mathrm{F}, \mathrm{R}$ \\
\hline S61 & $K n n$ & T & $\begin{array}{c}\text { OXA-1, CTX-M- } \\
15\end{array}$ & $\mathrm{~F}$ & $\mathrm{~F}$ \\
\hline S68 & K. pneumoniae & $\mathrm{Tc}$ & TEM-129 & $\mathrm{A} / \mathrm{C}$ & $\mathrm{A} / \mathrm{C}$ \\
\hline S72 & K. pneumoniae & $\mathrm{Tc}$ & SHV2a & $\mathrm{F}$ & $\mathrm{F}$ \\
\hline$S 73$ & K. pneumoniae & $\mathrm{Tc}$ & SHV-4 & $\mathrm{A} / \mathrm{C}$ & $\mathrm{A} / \mathrm{C}$ \\
\hline & & & OXA-1, CTX-M- & & \\
\hline $\mathrm{S} 75^{\dagger}$ & K. pneumoniae & $\mathrm{Tc}$ & 15 & FIIk & $\mathrm{F}$ \\
\hline S76 & K. pneumoniae & $\mathrm{Tc}$ & TEM-12 & $\mathrm{F}$ & $\mathrm{F}$ \\
\hline S77 & K. pneumoniae & $\mathrm{Tf}$ & SHV-12 & $\mathrm{R}$ & $\mathrm{R}$ \\
\hline S78 & K. pneumoniae & $\mathrm{Tc}$ & CTX-M-15 & FII & $\mathrm{F}$ \\
\hline
\end{tabular}




\begin{tabular}{|c|c|c|c|c|c|}
\hline S79 & K. pneumoniae & $\mathrm{Tc}$ & CTX-M-15 & $\mathrm{F}$ & $\mathrm{F}$ \\
\hline S82 & K. pneumoniae & $\mathrm{Tc}$ & CTX-M-15 & FII & $\mathrm{F}$ \\
\hline S83 & K. pneumoniae & $\mathrm{Tc}$ & TEM-3 & $\mathrm{A} / \mathrm{C}$ & $\mathrm{A} / \mathrm{C}$ \\
\hline S86 & K. pneumoniae & $\mathrm{Tc}$ & CMY-4 & $\mathrm{A} / \mathrm{C}$ & $\mathrm{A} / \mathrm{C}$ \\
\hline S88 & K. pneumoniae & $\mathrm{Tc}$ & SHV-2a & FIIk & $\mathrm{F}$ \\
\hline S89 & K. pneumoniae & $\mathrm{Tc}$ & TEM-21 & $\mathrm{A} / \mathrm{C}$ & $\mathrm{A} / \mathrm{C}$ \\
\hline $\mathrm{S} 90 \dagger$ & K. pneumoniae & $\mathrm{Tc}$ & $\begin{array}{c}\text { KPC } \\
\text { OXA-48, CTX-M- }\end{array}$ & X3 & $X$ \\
\hline FM1 & K. pneumoniae & $\mathrm{Tc}$ & $\begin{array}{c}15 \\
\text { OXA-48, CTX-M }\end{array}$ & $\mathrm{L} / \mathrm{M}$ & $\mathrm{L} / \mathrm{M}$ \\
\hline $\begin{array}{l}\text { FM2 } \\
\text { FUR- }\end{array}$ & K. pneumoniae & $\mathrm{Tc}$ & 15 & $\mathrm{~L} / \mathrm{M}$ & $\mathrm{L} / \mathrm{M}$ \\
\hline STA & K. pneumoniae & $\mathrm{Tc}$ & OXA-48 & $\mathrm{L} / \mathrm{M}$ & $\mathrm{L} / \mathrm{M}$ \\
\hline CLE-TN & K. pneumoniae & $\mathrm{Tc}$ & OXA-48 & $\mathrm{L} / \mathrm{M}$ & $\mathrm{L} / \mathrm{M}$ \\
\hline $\begin{array}{l}\text { PET-TN } \\
\text { MUR- }\end{array}$ & K. pneumoniae & $\mathrm{Tc}$ & OXA-48 & $\mathrm{L} / \mathrm{M}$ & $\mathrm{L} / \mathrm{M}$ \\
\hline STA & K. pneumoniae & $\mathrm{Tc}$ & NDM-1 & FIIk & $\mathrm{F}$ \\
\hline 2966 & K. pneumoniae & $\mathrm{Tc}$ & OXA-48 & $\mathrm{L} / \mathrm{M}$ & $\mathrm{L} / \mathrm{M}$ \\
\hline LD-1131 & K. pneumoniae & $\mathrm{Tc}$ & VIM & $\mathrm{R}$ & $\mathrm{R}$ \\
\hline LD-3856 & K. pneumoniae & $\mathrm{Tc}$ & OXA-48 & $\mathrm{L} / \mathrm{M}$ & $\mathrm{L} / \mathrm{M}$ \\
\hline Z-19760 & K. pneumoniae & $\mathrm{Tc}$ & OXA-48 & $\mathrm{L} / \mathrm{M}$ & $\mathrm{L} / \mathrm{M}$ \\
\hline Z-45518 & K. pneumoniae & $\mathrm{Tc}$ & OXA-48 & $\mathrm{L} / \mathrm{M}$ & $\mathrm{L} / \mathrm{M}$ \\
\hline Z-16300 & K. pneumoniae & $\mathrm{Tc}$ & OXA-48 & $\mathrm{L} / \mathrm{M}$ & $\mathrm{L} / \mathrm{M}$ \\
\hline Z-47994 & K. pneumoniae & $\mathrm{Tc}$ & OXA-48 & $\mathrm{L} / \mathrm{M}$ & $\mathrm{L} / \mathrm{M}$ \\
\hline Z-4359 & K. pneumoniae & $\mathrm{Tc}$ & OXA-48 & $\mathrm{L} / \mathrm{M}$ & $\mathrm{L} / \mathrm{M}$ \\
\hline MIKH & K. pneumoniae & $\mathrm{Tc}$ & OXА-48, CTX-M9 & HI1 & $\mathrm{HIb}$ \\
\hline BHR & K. pneumoniae & $\mathrm{Tc}$ & VIM-4, CTX-M-1 & HI1 & $\mathrm{HIb}$ \\
\hline M-4 & K. pneumoniae & $\mathrm{Tc}$ & KPC-2 & $\mathrm{L} / \mathrm{M}$ & $\mathrm{L} / \mathrm{M}$ \\
\hline M-6 & $K$. pneumoniae & $\mathrm{Tc}$ & KPC-2 & $\mathrm{L} / \mathrm{M}$ & $\mathrm{L} / \mathrm{M}$ \\
\hline M-7 & K. pneumoniae & $\mathrm{Tc}$ & KPC-2 & $\mathrm{L} / \mathrm{M}$ & $\mathrm{L} / \mathrm{M}$ \\
\hline M-14 & K. pneumoniae & $\mathrm{Tc}$ & KPC-2 & $\mathrm{L} / \mathrm{M}$ & $\mathrm{L} / \mathrm{M}$ \\
\hline M-20 & K. pneumoniae & $\mathrm{Tc}$ & KPC-2 & $\mathrm{L} / \mathrm{M}$ & $\mathrm{L} / \mathrm{M}$ \\
\hline M-32 & K. pneumoniae & $\mathrm{Tc}$ & KPC-2 & $\mathrm{L} / \mathrm{M}$ & $\mathrm{L} / \mathrm{M}$ \\
\hline M-40 & K. pneumoniae & $\mathrm{Tc}$ & KPC-2 & $\mathrm{L} / \mathrm{M}$ & $\mathrm{L} / \mathrm{M}$ \\
\hline M-41 & K. pneumoniae & $\mathrm{Tc}$ & KPC-2 & $\mathrm{L} / \mathrm{M}$ & $\mathrm{L} / \mathrm{M}$ \\
\hline M-50 & K. pneumoniae & $\mathrm{Tc}$ & KPC-2 & $\mathrm{L} / \mathrm{M}$ & $\mathrm{L} / \mathrm{M}$ \\
\hline M-52 & K. pneumoniae & $\mathrm{Tc}$ & KPC-2 & $\mathrm{L} / \mathrm{M}$ & $\mathrm{L} / \mathrm{M}$ \\
\hline $\begin{array}{l}\text { M-53 } \\
\text { TNDHA }\end{array}$ & K. pneumoniae & $\mathrm{Tc}$ & KPC-2 & $\mathrm{L} / \mathrm{M}$ & $\mathrm{L} / \mathrm{M}$ \\
\hline $\begin{array}{l}-5 \\
\text { TNDHA }\end{array}$ & K. pneumoniae & $\mathrm{Tc}$ & DHA-1, SHV-12 & $\mathrm{HI} 2$ & $\mathrm{HIb}$ \\
\hline $\begin{array}{l}-6 \\
\text { TNDHA }\end{array}$ & K. pneumoniae & $\mathrm{Tc}$ & DHA-1, SHV-12 & $\mathrm{HI} 2$ & $\mathrm{HIb}$ \\
\hline $\begin{array}{l}-7 \\
\text { TNDHA }\end{array}$ & K. pneumoniae & $\mathrm{Tc}$ & DHA-1, SHV-12 & HI2 & $\mathrm{HIb}$ \\
\hline-8 & $\begin{array}{l}\text { K. pneumoniae } \\
\text { S. enterica }\end{array}$ & $\mathrm{Tc}$ & DHA-1, SHV-12 & HI2 & $\mathrm{HIb}$ \\
\hline S00056 & $\begin{array}{l}\text { Typhimurium } \\
\text { S. enterica }\end{array}$ & $\mathrm{Tc}$ & CTX-M-2 & HI2 & HIa \\
\hline S00319† & Havana & $\mathrm{Tc}$ & CTX-M-15 & $\mathrm{HI} 2$ & HIa \\
\hline
\end{tabular}


S. enterica Tel

\begin{tabular}{|c|c|c|c|c|c|}
\hline S01331 & $\begin{array}{l}\text { el kebir } \\
\text { S. enterica }\end{array}$ & $\mathrm{Tc}$ & CTX-M-15 & HI2 & HIa \\
\hline S01477† & $\begin{array}{l}\text { Typhimurium } \\
\text { S. enterica }\end{array}$ & $\mathrm{Tc}$ & CTX-M-1/CMY-2 & HI1, I1 & $\mathrm{I} 1, \mathrm{HIb}$ \\
\hline S01650 & $\begin{array}{l}\text { Brandeburg } \\
\text { S. enterica }\end{array}$ & $\mathrm{Tc}$ & CTX-M-14 & FrepB & $\mathrm{F}$ \\
\hline S03207 & $\begin{array}{l}\text { Typhimurium } \\
\text { S. enterica }\end{array}$ & $\mathrm{Tf}$ & CTX-M-15 & IA, FIB & $\mathrm{F}$ \\
\hline S03663 & $\begin{array}{l}\text { Grumpensis } \\
\text { S. enterica }\end{array}$ & $\mathrm{Tc}$ & CTX-M-15 & HI2 & HIa \\
\hline S03664 & $\begin{array}{l}\text { Typhimurium } \\
\text { S. enterica }\end{array}$ & $\mathrm{Tc}$ & CTX-M-15 & $\mathrm{N}$ & $\mathrm{N}$ \\
\hline S04662 & $\begin{array}{l}\text { Virchow } \\
\text { S. enterica }\end{array}$ & $\mathrm{Tc}$ & $X_{-}$ & $\mathrm{N}$ & $\mathrm{N}$ \\
\hline S05343 & $\begin{array}{l}\text { Concord } \\
\text { S. enterica }\end{array}$ & $\mathrm{Tc}$ & CTX-M-15 & $\mathrm{HI} 2$ & HIa \\
\hline S07364 & $\begin{array}{l}\text { Miami } \\
\text { S. enterica }\end{array}$ & $\mathrm{Tc}$ & SHV-2 & $\mathrm{N}$ & $\mathrm{N}$ \\
\hline S09118 & $\begin{array}{l}\text { Keurmassar } \\
\text { S. enterica }\end{array}$ & $\mathrm{Tc}$ & SHV-12 & $\mathrm{HI} 2, \mathrm{FI}$ & F, HIa \\
\hline S27078 & $\begin{array}{l}\text { Carmel } \\
\text { S. enterica }\end{array}$ & & CTX-M-15 & FrepB & $\mathrm{F}$ \\
\hline S7917 & $\begin{array}{l}\text { Derby } \\
\text { S. enterica }\end{array}$ & & ND & FIA & $\mathrm{F}$ \\
\hline S7981 & $\begin{array}{l}\text { Saintpaul } \\
\text { S. enterica }\end{array}$ & & OXA-48 & $\mathrm{L} / \mathrm{M}$ & $\mathrm{L} / \mathrm{M}$ \\
\hline M-1 & $\begin{array}{l}\text { Enteritidis } \\
\text { S. enterica }\end{array}$ & $\mathrm{Tc}$ & KPC-2 & $\mathrm{L} / \mathrm{M}$ & $\mathrm{L} / \mathrm{M}$ \\
\hline$S 1106 \dagger$ & Virchow & $\mathrm{Tc}$ & SHV-12 & I1 & I1 \\
\hline
\end{tabular}


Table 3. Plasmid partition gene typing of 30 clinical strains of Enterobacteriaceae.

\begin{tabular}{|c|c|c|c|c|c|c|c|c|}
\hline \multirow[b]{2}{*}{$\mathrm{N}^{\circ}$} & \multirow[b]{2}{*}{ Parental species } & \multirow[b]{2}{*}{$\begin{array}{c}\beta- \\
\text { Lactam } \\
\text { ase }\end{array}$} & \multirow[b]{2}{*}{$\begin{array}{c}\text { PRase } \\
\mathrm{T}\end{array}$} & \multicolumn{5}{|c|}{ PAR-T } \\
\hline & & & & $\begin{array}{c}\text { Multip } \\
\text { lex I } \\
\text { and II }\end{array}$ & $\begin{array}{c}\text { Multipl } \\
\text { ex III }\end{array}$ & $\begin{array}{l}\text { Multipl } \\
\text { ex IV }\end{array}$ & $\begin{array}{c}\text { Multipl } \\
\text { ex V }\end{array}$ & $\begin{array}{c}\text { Simple } \\
\text { x VI }\end{array}$ \\
\hline 3 & E. coli & $\begin{array}{c}\text { TEM- } \\
24 \\
\end{array}$ & $\mathrm{~A} / \mathrm{C}$ & & $\mathrm{A} / \mathrm{C}$ & & & \\
\hline 15 & E. coli & $\begin{array}{c}\text { TEM- } \\
24\end{array}$ & $\mathrm{~A} / \mathrm{C}, \mathrm{I} 1$ & & $\mathrm{~A} / \mathrm{C}$ & & $\mathrm{I} 1$ & \\
\hline 17 & E. coli & $\begin{array}{c}\text { TEM- } \\
24\end{array}$ & $\begin{array}{c}\mathrm{A} / \mathrm{C}, \mathrm{F}, \\
\mathrm{HI} 2 \\
\mathrm{X} 4\end{array}$ & $\mathrm{~F}$ & $\mathrm{~A} / \mathrm{C}$ & HI & & - \\
\hline 19 & E. coli & $\begin{array}{c}\text { TEM- } \\
21\end{array}$ & $\begin{array}{c}\mathrm{A} / \mathrm{C}, \\
\mathrm{N}, \mathrm{X} 1\end{array}$ & $\mathrm{~F}$ & $\mathrm{~A} / \mathrm{C}, \mathrm{N}$ & & & - \\
\hline 23 & E. coli & $\begin{array}{c}\text { TEM- } \\
24\end{array}$ & $\begin{array}{c}\mathrm{A} / \mathrm{C}, \mathrm{F}, \\
\mathrm{I} 1\end{array}$ & $\mathrm{~F}$ & $\mathrm{~A} / \mathrm{C}$ & & I1 & \\
\hline 26 & E. coli & $\begin{array}{c}\text { TEM- } \\
24\end{array}$ & $\begin{array}{c}\mathrm{A} / \mathrm{C}, \mathrm{F}, \\
\mathrm{HI} 1\end{array}$ & F & $\mathrm{A} / \mathrm{C}$ & HIa & & \\
\hline 28 & E. coli & $\begin{array}{c}\text { TEM- } \\
21 \\
\end{array}$ & $\begin{array}{c}\mathrm{A} / \mathrm{C} \\
\mathrm{X} 1\end{array}$ & & $\mathrm{~A} / \mathrm{C}$ & & & - \\
\hline 33 & E. coli & $\begin{array}{c}\text { TEM- } \\
24\end{array}$ & $\mathrm{~A} / \mathrm{C}$ & & $\mathrm{A} / \mathrm{C}$ & & & \\
\hline 34 & E. coli & $\begin{array}{c}\text { TEM- } \\
24 \\
\end{array}$ & $\begin{array}{c}\mathrm{A} / \mathrm{C}, \\
\mathrm{N}, \mathrm{X} 1\end{array}$ & $\mathrm{~F}$ & $\mathrm{~A} / \mathrm{C}, \mathrm{N}$ & & & - \\
\hline 40 & E. coli & $\begin{array}{c}\text { TEM- } \\
24\end{array}$ & $\mathrm{~A} / \mathrm{C}, \mathrm{F}$ & $\mathrm{F}$ & $\mathrm{A} / \mathrm{C}$ & & & \\
\hline 50 & E. coli & $\begin{array}{c}\text { TEM- } \\
52\end{array}$ & I1 & & & & I1 & \\
\hline 84 & E. coli & $\begin{array}{l}\text { CTX- } \\
\text { M-1 }\end{array}$ & $\begin{array}{c}\text { F HI1, } \\
\mathrm{N}\end{array}$ & $\mathrm{F}$ & $\mathrm{N}$ & $\mathrm{HIb}$ & & \\
\hline 88 & E. coli & $\begin{array}{l}\text { CTX- } \\
\text { M-1 }\end{array}$ & $\begin{array}{c}\mathrm{F}, \mathrm{HI} 1, \\
\mathrm{~N}\end{array}$ & $\mathrm{~F}$ & $\mathrm{~N}$ & HIa & & \\
\hline 101 & E. coli & $\begin{array}{l}\text { CTX- } \\
\text { M-2 }\end{array}$ & HI2 & & & Hia & & \\
\hline 105 & E. coli & $\begin{array}{l}\text { CTX- } \\
\text { M-1 }\end{array}$ & $\begin{array}{c}\text { L/M, } \\
\text { I1 }\end{array}$ & & $\mathrm{L} / \mathrm{M}$ & & - & \\
\hline 106 & E. coli & $\begin{array}{l}\text { CTX- } \\
\text { M-1 }\end{array}$ & $\begin{array}{c}\mathrm{F}, \mathrm{HI} 1, \\
\mathrm{~N}\end{array}$ & $\mathrm{~F}$ & $\mathrm{~N}$ & HIa & & \\
\hline 107 & E. coli & $\begin{array}{c}\text { CTX- } \\
\text { M-2 }\end{array}$ & $\mathrm{I} 1, \mathrm{~F}$ & $\mathrm{~F}$ & & & I1 & \\
\hline $\begin{array}{c}\mathrm{KpS} \\
5\end{array}$ & K. pneumoniae & DHA-1 & $\begin{array}{l}\text { FIIK, } \\
\text { L/M }\end{array}$ & $\mathrm{F}$ & $\mathrm{L} / \mathrm{M}$ & & $\mathrm{R}$ & \\
\hline $\begin{array}{c}\mathrm{KpS} \\
19 \\
\end{array}$ & K. pneumoniae & $\begin{array}{c}\text { CTX- } \\
\text { M-15, } \\
\text { DHA-1 }\end{array}$ & $\begin{array}{c}\text { FIIK, } \\
\text { F, } \\
\text { L/M, N }\end{array}$ & $\mathrm{F}$ & $\mathrm{L} / \mathrm{M}, \mathrm{N}$ & & & \\
\hline $\begin{array}{c}\mathrm{KpS} \\
20 \\
\end{array}$ & K. pneumoniae & $\begin{array}{c}\text { CTX- } \\
\text { M- } \\
15, \mathrm{SH} \\
\end{array}$ & $\mathrm{F}, \mathrm{X} 4$ & $\mathrm{~F}$ & & & & - \\
\hline
\end{tabular}




\begin{tabular}{|c|c|c|c|c|c|c|c|}
\hline & & $\mathrm{V}-2 \mathrm{a}$ & & & & & \\
\hline $\begin{array}{c}\mathrm{KpS} \\
26 \\
\end{array}$ & K. pneumoniae & $\begin{array}{c}\text { SHV- } \\
12 \\
\end{array}$ & $\begin{array}{c}\text { FIIK, } \\
\mathrm{N}\end{array}$ & $\mathrm{F}$ & $\mathrm{N}$ & & $\mathrm{R}$ \\
\hline $\begin{array}{c}\mathrm{KpS} \\
47\end{array}$ & K. pneumoniae & $\begin{array}{l}\text { CTX- } \\
\text { M-3 }\end{array}$ & $\begin{array}{l}\text { HI2, } \\
\text { L/M }\end{array}$ & & $\mathrm{L} / \mathrm{M}$ & HIa & \\
\hline $\begin{array}{c}\mathrm{KpS} \\
63\end{array}$ & K. pneumoniae & DHA-1 & $\begin{array}{l}\text { FIIK, } \\
\text { L/M }\end{array}$ & $\mathrm{F}$ & $\mathrm{L} / \mathrm{M}$ & & \\
\hline $\begin{array}{c}\mathrm{KpS} \\
83 \\
\end{array}$ & K. pneumoniae & TEM-3 & $\begin{array}{c}\mathrm{A} / \mathrm{C}, \mathrm{F}, \\
\mathrm{N}\end{array}$ & & & & \\
\hline $\begin{array}{c}\mathrm{KpS} \\
88\end{array}$ & K. pneumoniae & $\begin{array}{l}\text { SHV- } \\
2 \mathrm{a}\end{array}$ & FIIK & $\mathrm{F}$ & & & \\
\hline $\begin{array}{c}\mathrm{KpS} \\
92\end{array}$ & K. pneumoniae & $\begin{array}{l}\text { CTX- } \\
\text { M-14, } \\
\text { VIM-1 }\end{array}$ & $\begin{array}{l}\text { F, } \\
\text { FIIK, } \\
\text { I1 }\end{array}$ & $\mathrm{F}$ & & & I1 \\
\hline $\begin{array}{l}\text { FM- } \\
2\end{array}$ & K. pneumoniae & $\begin{array}{c}\text { OXA- } \\
48\end{array}$ & $\begin{array}{c}\text { FIIK, } \\
\text { L/M, N }\end{array}$ & & $\mathrm{L} /$ & & \\
\hline $\begin{array}{c}\text { FM- } \\
10\end{array}$ & K. pneumoniae & $\begin{array}{l}\text { OXA- } \\
48\end{array}$ & $\begin{array}{l}\mathrm{A} / \mathrm{C}, \\
\mathrm{L} / \mathrm{M}\end{array}$ & & $\begin{array}{l}\mathrm{A} / \mathrm{C}, \\
\mathrm{L} / \mathrm{M}\end{array}$ & & \\
\hline $\begin{array}{l}\text { S10- } \\
1477\end{array}$ & $\begin{array}{c}\text { S. enterica } \\
\text { Typhimurium }\end{array}$ & $\begin{array}{c}\text { CTX- } \\
\text { M-1, } \\
\text { CMY- } \\
2\end{array}$ & & & & $\mathrm{HIb}$ & I1 \\
\hline $\begin{array}{l}\text { S10- } \\
1526\end{array}$ & $\begin{array}{l}\text { S. enterica } \\
\text { Typhimurium }\end{array}$ & $\begin{array}{l}\text { CTX- } \\
\text { M-1, } \\
\text { CMY- } \\
2\end{array}$ & HI1, I1 & & & $\mathrm{HIb}$ & I1 \\
\hline
\end{tabular}




\section{$\underline{\text { Highlights }}$}

-Low-copy-number plasmids utilize partition systems for plasmid maintenance.

-par loci are organized into operons encoding two proteins, an ATPase and a DNA-binding protein, and including a centromeric site.

-The method called "plasmid partition gene typing" showed high specificity for the classification of resistance plasmids (IncA/C, FIA, FIB, FIC, FIIk, FII, HI1, HI2, I1, L/M, N) except for IncX replicons. 